\title{
Pemanfaatan Formula Coating untuk Meningkatkan Mutu dan Kesehatan Benih Padi (Oryza sativa L.) Selama Penyimpanan
}

\author{
Aloysius Rusae ${ }^{\mathrm{a}}$, Anna Tefa ${ }^{\mathrm{b}}$, Maria Matilde Nesi Seran ${ }^{\mathrm{c}}$ \\ ${ }^{a}$ Fakultas Pertanian, Universitas Timor, Kefamenanu, TTU - NTT, Indonesia, email: alorusae@yahoo.com \\ ${ }^{b}$ Fakultas Pertanian, Universitas Timor, Kefamenanu, TTU - NTT, Indonesia, email: annatefa@ rocketmail.com \\ ${ }^{c}$ Fakultas Pertanian, Universitas Timor, Kefamenanu, TTU - NTT, Indonesia, email: mariaseran2019s@ gmail.com
}

\section{Article Info}

\section{Article history:}

Received 07 Juli 2019

Received in revised form 10 November 2019

Accepted 14 Januari 2020

DOI:

https://doi.org/10.32938/sc.v4i01.813

Keywords:

Benih padi

MOL

Lama Penyimpanan

Pelapisan (Coating)

PGPR

Periode simpanan

\section{Abstrak}

Padi merupakan salah satu komoditas pangan karena banyak di konsumsi oleh sebagian besar masyarkakat di Indonesia. Tujuan penelitian ini adalah untuk meningkatkan mutu dan kesehatan benih padi lewat proses coating. Penelitian ini dilaksanakan di Laboratorium Fakultas Pertanian Universitas Timor pada bulan Februari-Mei 2010. Penelitian ini menggunakan Rancangan Acak Lengkap pola faktorial. Faktor pertama adalah perlakuan coating yang terdiri dari 3 aras yaitu tanpa coating, coating dengan PGPR, dengan MOL. Faktor kedua adalah periode simpanan yang terdiri dari 4 aras yaitu tanpa penyimpanan, penyimpanan bulan ke-1, penyimpanan bulan ke-2, penyimpanan bulan ke-3. Hasil penelitian menunjukkan bahwa terjadi interaksi pada semua parameter pengamatan kecuali pada parameter pengamatan berat kecambah normal, dengan kombinasi perlakuan terbaik adalah perlakuan coating dengan PGPR dengan lama penyimpanan 1 bulan yang ditunjukkan dengan parameter pengamatan daya berkecambah terbaik, indeks vigor terbaik, dan kejadian penyakit terendah

\section{Pendahuluan}

Padi merupakan salah satu komoditas pangan karena banyak dikonsumsi oleh sebagian besar masyarakat di Indonesia. Luas panen tanaman padi di tahun 2008 mencakup 11377 934,44 ha dengan produktivitas rata-rata 5,2 t/ha dan tahun 20019 luas panen mencakup $10.677 .887,15$ ha dengan produktifitas ratarata 5,11 t/ha. Namun produksi Padi masih tetap saja lebih rendah jika dibandingkan dengan potensi sebelumnya yaitu 7-8 ha- ${ }^{-1}$. Badan Pusat Statistik (2009) menjelaskan bahwa menurunnya nilai produktivitas padi karena penggunaan benih Padi yang kurang berkualitas. Keberhasilan nilai produktivitas dapat ditentukan oleh mutu benih karena peranannya tidak dapat digantikan oleh faktor lain. Maka dari itu harus perlu di perhatikan ketersedian mutuh benihnya. Ketersediaan benih bermutu dapat menyebabkan tanaman yang akan dihasilkan memiliki kualitas yang baik dan tingkat produksinya semakin tinggi. Benih merupakan bahan tanam yang menentukan awal keberhasilan suatu proses produksi. Sebelum menjadi tanaman, benih harus melalui proses perkecambahan terlebih dahulu. Beberapa hal yang dapat menyebabkan turunnya mutu benih adalah kadar air yang tidak tepat selama periode penyimpanan. Hal ini akan meningkatkan laju deteriorasi, sehingga viabilitas dan vigor benih cepat menurun (Hendarto, 2005).

Benih yang bermutu adalah benih yang benih yang memiliki viabilitas dan vigor yang cukup tinggi, namun vigor benih dapat mengalami suatu kemunduran karena prosesnya bersamaan dengan lamanya suatu penyimpanan sehingga benih tersebut dapat mengalami kemunduran dapat terjadi karena adanya enzim-enzim yang mengalami degradasi dan sudah tidak aktif lagi (Copeland \& Mc Donald, 2001). Suatu proses dalam kemunduran benih dapat dilihat dari sifat yang tidak dapat berbalik karena adanya penerapan sebuah ilmu dan teknologi yang dapat disesuiakan maka proses kemunduran pada benih dapat dikendalikan sehingga prosesnya dapat berlangsung dengan lambat (Roesli dalam Justice \& Bass,2002).

Peningkatan kualitas dan kuantitas dalam produksi Padi adalah salah satu faktor penggunaan benih yang mutunya tinggi. Mutu benih dapat terdiri dari mutu genetis dalam mutu genetis itu dapat menjabarkan sifat unggul yang diwariskan oleh induk, mutu fisik dapat dilihat pada struktur morfologinya, ukurannya, berat, dan penampakan benih, mutu fisiologis meliputi viabilitas dan vigor benih, mutu patologis dapat menunjukan pada keberadaan infeksi penyakit terbawah benih (seed borne) atau kesehatan benih (seed health) (Ilyas, 2012).

Seed coating merupakan suatu proses dimana pembungkusan benih dengan menggunakan zat tertentu, yang bertujuan agar mampu meningkatkan kerja suatu benih saat berkecambah, dimana benih tersebut dapat terlindung dari suatu gangguan maupun pengaruh buruk dari suatu kondisi lingkungan dalam melakukan suatu penyimpanan maupun dari dalam rantai pemasaran untuk dapat mempertahankan kadar air dalam suatu benih, sehingga dapat menyeragamkan ukuran benih, pemindaan penyimpanan benih, mengurangi dampak maupun kondisi tempat penyimpanan, serta dapat memperpanjang suatu daya penyimpanan benih (Kuswanto, 2003).

Bakteri Plant Growth Promoting Rhizobacteria (PGPR) merupakan bakteri pemacu pertumbuhan tanaman yang hidup di rizosfer tanaman serta dapat digunakan sebagai agen pengendali hayati beberapa jenis patogen. Perlakuan benih dengan PGPR dapat meningkatkan mekanisme pertahanan tanaman terhadap serangan patogen. Sifat endofitik (berada dalam jaringan tanaman dan tidak berbahaya bagi tanaman) menyebabkan PGPR tepat digunakan saat vegetatif tanaman karena dapat mengurangi kebutuhan untuk aplikasi lebih lanjut jika bagian-bagian vegetatif yang sama digunakan sebagai bahan propagatif (Ramamoorthy et al. 2000). Teknologi pengendalian yang aman dan mampu untuk mengendalikan virus adalah suatu suatu pemanfaatan Plant Growth Promoting Rhizobacteria (PGPR). PGPR merupakan sekumpulan bakteri yang berkolonia dan mampu hidup pada akar tanaman. Manfaat lain PGPR adalah untuk merangsang pertunbuhan (biostimulan), penyedia hara (biofertilizer), dan dapat mengendalikan patogen (bioprotektan) (Millan, 2007). Berdasarkan uraian diatas maka penelitian ini bertujuan untuk meningkatkan mutu dan kesehatan benih Padi melalui proses coating benih

\section{Metode}

Penelitian ini dilaksanakan pada bulan Februari - Mei 2019 di Laboratorium Fakultas Pertanian Universitas Timor, KelurahanSasi, Kecamatan Kota Kefamenanu, Kabupaten Timor Tengah Utara. Penelitian ini menggunakan Rancangan Acak Lengkap (RAL) pola faktorial. Faktor pertama adalah perlakuan coting yang terdiri dari 3 aras yaitu: $\mathrm{C}_{0}=$ tanpa coating, $\mathrm{C}_{1}=$ Coating dengan PGPR, $\mathrm{C}_{2}=$ Coating dengan mikroorganisme lokal (Mol). Faktor kedua adalah periode simpan yang terdiri dari 4 aras yaitu: $\mathrm{P}_{0}=$ tanpa penyimpanan, $\mathrm{P}_{1}=$ penyimpanan 1 bulan, $\mathrm{P}_{2}=$ penyimpanan 2 bulan, $\mathrm{P}_{3}=$ penyimpanan 3 bulan, dengan kombinasi perlakuannya adalah $\mathrm{C}_{0} \mathrm{P}_{0}, \mathrm{C}_{0} \mathrm{P}_{1}$ $\mathrm{C}_{0} \mathrm{P}_{2}, \mathrm{C}_{0} \mathrm{P}_{3}, \mathrm{C}_{1} \mathrm{P} 0, \mathrm{C}_{1} \mathrm{P}_{1}, \mathrm{C}_{1} \mathrm{P}_{2}, \mathrm{C}_{1} \mathrm{P}_{3}, \mathrm{C}_{2} \mathrm{P}_{0}, \mathrm{C}_{2} \mathrm{P}_{1}, \mathrm{C}_{2} \mathrm{P}_{2}, \mathrm{C}_{2} \mathrm{P}_{3}$. Semua Perlakuan diulang sebanyak 4 kali sehingga terdapat 48 unit satuan penelitian.

Benih yang digunakan adalah benih yang baik, tidak mengandung penyakit, warna benih cerah, ukuran benihnya normal dan seragam. Untuk mengetahui bahwa benih itu sehat maka terlebih dahulu dilakukannya sortas benih. Setelah melakukan sortasi, benih disterilkan dengan merendam benih dengam $\mathrm{NaOcl}$ dan aquadest selama 3 menit kemudian dicuci dengan menggunakan aquadest steril sebanyak 3 kali. Proses coating dapat dilakukan secara manual, benih padi sebanyak 50 gram: PGPR 0,25 gram : X hantam Gum 2 gram. Agar benih hasil coating terlihat jelas perbedaanya dengan benih tanpa coating maka dapat ditambahkan pewarna makanan sebanyak $1 \mathrm{ml}$. Benih yang di coating dapat dikering anginkan dalam laminar air flow cabinnet selama 24 jam sampai benih aman kemudian disimpan sesuai dengan perlakuan lama waktu penyimpanan. Setelah benih disimpan dan mencapai umur lama penyimpanan maka benih dapat ditanaman menggunakan teknik uji diatas kertas (UDK) dengan masing-masing perlakuan ditanamn sebanyak 25 butir benih yang terdiri dari 4 ulangan sehingga setiap ulangan terdapat 25 butir benih padi. Pengamatan dapat dilakukan pada hitungan pertama sampai selesai. Parameter yang diamati sebagaiberikut:

\section{Potensi Tumbuh Maksimum (PTM)}

Potensi Tumbuh Maksimum (PTM) (\%) Potensi tumbuh maksimum diperoleh dengan menghitung jumlah kecambah yang tumbuh normal maupun abnormal pada 7 HST (hari setelah tanam). Potensi tumbuh maksimum dihitung dengan rumus:

$$
\mathrm{PTM}=\frac{\sum K N+\sum \mathrm{Kab}}{\sum \text { benih yang ditanaman }} \times 100 \%
$$

Dimana: $\Sigma K N=$ Jumlah kecambah normal sampai akhir pengamatan, $\Sigma K A b=$ Jumlah kecambah abnormal sampai akhir pengamatan

\section{Daya Berkecambah (DB)}

Daya Berkecambah (DB) (\%) Daya berkecambah diperoleh dengan menghitung jumlah benih yang berkecambah normal pada 5 dan 7 HST. Daya berkecambah benih dihitung dengan rumus:

$$
\mathrm{DB}=\frac{\sum K N \text { hitungan } 1+\sum \mathrm{KN} \text { hitunganII }}{\sum \text { benihyangdikecambah }} \times 100 \%
$$

Dimana: $\Sigma K N=$ Jumlah kecambah normal 


\section{Indeks Vigor (IV)}

Perhitungan didasari pada persentase kecambah normal $(\mathrm{KN})$ dihitung pertama pada uji daya berkecambah yaitu 5 HST untuk benih padi, dengan rumus:

$$
\begin{aligned}
& \mathrm{IV}=\frac{\sum K N \text { hitunganI }}{\sum \text { benihyangditanamam }} \times 100 \% \\
& K N=\text { Persentase kecambah normal }
\end{aligned}
$$

Dimana: $\Sigma K N=$ Persentase kecambah normal

\section{Kecepatan Tumbuh (KCT)}

Kecepatan Tumbuh (KCT) (\%/etmal) Kecepatan tumbuh dihitung setiap hari selama 7 hari pada benih yang tumbuh normal. Kecepatan tumbuh dihitung dengan rumus:

$$
\mathrm{KCT}=\frac{\% K N k e-2}{\text { etmal }}+\cdots+\frac{\% \mathrm{KN} \mathrm{ke}-\mathrm{n}}{\text { etmal }}
$$

Dimana: 1 et mal $=24$ jam, \% KN=Persentase kecambah normal

\section{Keserempakan Tumbuh $(\%)$}

Keserampakan tumbuh dihitung berdasarkan persentase kecambah normal pada 6 hari setelah tanam. Pengamatan dilakukan terhadap jumlah bibit normal diantara hitungan pertama dan hitungan kedua. Keserempakan tumbuh dapat dihitung dengan rumus:

$$
\mathrm{KT}=\frac{\sum K N \mathrm{ke}-5}{\sum \text { benihyangditanaman }} \times 100 \%
$$

Dimana: $\sum K N=$ Jumlah kecambah normal

\section{Berat Kering Kecambah Normal (BKKN)}

Berat Kering Kecambah Normal diamati pada hari hari ke-7 dengan cara memisahkan kecambah normal dari cadangan makanannya kecambah tersebut dapat dimasukkan kedalam amplop dan dioven pada suhu $60^{\circ} \mathrm{C}$ selama $3 \times 24$ jam. Setelah dioven, amplop yang berisi kecambah tersebut dimasukkan kedalam desikator selama \pm 45 menit kemudian ditimbang.

\section{Kejadian penyakit}

Menurut Zadok dan Schein(1979) menghitung persentase kejadian penyakit (KP) digunakan rumus sebagai berikut:

$$
\mathrm{KP}=\frac{n}{N} \times 100 \%
$$

$K p=$ Kejadian Penyakit, $n=$ Jumlah tanaman yang terserang patogen $N=$ Jumlah tanaman yang diamati dalam setiap perlakuan

Data hasil pengamatan dianalisis dengan menggunakan sidik ragam (Anova). Rancangan Acak Lengkap (RAL). Rata-rata perlakuan dapat diuji lanjut dengan menggunakan Duncan Multiple Range Test (DMRT) dengan tingkat signifikasi $5 \%$. Analisis data menggunakan program SAS 9.1.

\section{Hasil dan Pembahasan \\ $3.1 \quad$ Hasil}

\section{Potensi Tumbuh Maksimum (PTM)}

Hasil sidik ragam (Anova) menunjukkan bahwa terjadi interaksi antara perlakuan coating dan penyimpanan. Perlakuan coating MOL pada penyimpanan bulan ke-3 menunjukkan hasil potensi tumbuh maksimum terbaik dengan presentasi tertinggi $95,00 \%$ berbeda nyata dengan perlakuan lainnya (Tabel. 1).

Tabel 1. Potensi Tumbuh Maksimum

\begin{tabular}{ccccc}
\hline \multirow{2}{*}{ Lama Penyimpanan (Bulan) } & \multicolumn{3}{c}{ Coating } & \multirow{2}{*}{ Rerata } \\
\cline { 2 - 4 } & Kontrol & PGPR & Mol & \\
\hline Tanpa (kontrol) & $84,00^{\text {bcde }}$ & $89,00^{\text {abcd }}$ & $90,50^{\text {abc }}$ & 87,83 \\
Penyimpanan 1 & $90,00^{\text {abcd }}$ & $92,00^{\text {ab }}$ & $93,00^{\text {ab }}$ & 91,67 \\
Penyimpanan 2 & $84,00^{\text {bcde }}$ & $79,00^{\mathrm{e}}$ & $85,00^{\text {bcde }}$ & 82,67 \\
Penyimpanan 3 & $95,00^{\text {a }}$ & $81,00^{\text {ed }}$ & $82,00^{\text {cde }}$ & 86,00 \\
\hline Rerata & 88,25 & 85,25 & 87,63 & $(+)$ \\
\hline
\end{tabular}

Keterangan: Angka pada barisan dan kolom yang diikuti huruf yang sama menunjukkan tidak beda nyata pada tingkat (a) 5\% menurut uji DMRT. (+): Terjadi Interaksi

\section{Daya Berkecambah}

Hasil sidik ragam (Anova) menunjukkan bahwa terjadi interaksi antara perlakuan coating dengan penyimpanan. Perlakuan coating PGPR yang disimpan pada bulan ke-1 menunjukkan bahwa daya berkecambah terbaik $97,00 \%$ berbeda nyata dengan perlakuan tanpa coating dan perlakuan coating MOL (Tabel. 2)

\section{Indeks Vigor}

Hasil sidik ragam (Anova) menunjukkan bahwa terjadi interaksi antara perlakuan dan penyimpanan. Tanpa perlakuan coating yang disimpan pada bulan ke-1 menunjukkan hasil indeks vigor terbaik dengan presentase $92,00 \%$ dan ada beda nyata antara tanpa coating dengan perlakuan lainnya (Tabel. 3)

\section{Kecepatan Tumbuh}

Hasil sidik ragam (anova) menunjukkan bahwa terjadi interaksi antara perlakuan coating dengan penyimpanan. Perlakuan coating PGPR yang

\begin{tabular}{|c|c|c|c|c|}
\hline \multirow[b]{2}{*}{ Lama Penyimpanan (Bulan) } & \multicolumn{3}{|c|}{ Coating } & \multirow{2}{*}{ Rerata } \\
\hline & Kontrol & PGPR & Mol & \\
\hline Tanpa (kontrol) & $94,66^{\mathrm{a}}$ & $86,00^{\mathrm{ab}}$ & $88,50^{\mathrm{ab}}$ & 89,50 \\
\hline Penyimpanan 1 & $85,00^{\mathrm{ab}}$ & $97,00^{\mathrm{a}}$ & $80,00^{\mathrm{b}}$ & 87,33 \\
\hline Penyimpanan 2 & $81,00^{\mathrm{b}}$ & $80,00^{\mathrm{b}}$ & $79,00^{\mathrm{b}}$ & 84,67 \\
\hline Penyimpanan 3 & $95,00^{\mathrm{a}}$ & $88,00^{\mathrm{ab}}$ & $86,00^{\mathrm{ab}}$ & 89,67 \\
\hline Rerata & 92,25 & 87,75 & 83,38 & $(+)$ \\
\hline
\end{tabular}
disimpan selama 2 bulan menunjukan kecepatan tumbuh terbaik dengan presentasi tertinggi 22,29/etmal berbeda nyata dengan tanpa coating dan perlakuan coating MOL (Tabel. 4)
Keterangan : Angka pada barisan dan kolom diikuti huruf yang sama menunjukkan tidak beda nyata pada tingkat( $\alpha$ ) 5\% menurut uji DMRT. (+): Terjadi Interaksi

\begin{tabular}{ccccc}
\multicolumn{5}{l}{ Tabel 3. Indeks Vigor } \\
\hline \multirow{2}{*}{ Lama Penyimpanan (Bulan) } & \multicolumn{3}{c}{ Coating } \\
\cline { 2 - 4 } & Kontrol & PGPR & Mol & \\
\hline Tanpa (kontrol) & $81.33^{\mathrm{ab}}$ & $88,00^{\mathrm{ab}}$ & $84,00^{\mathrm{ab}}$ & 86,00 \\
Penyimpanan 1 & $92,00^{\mathrm{a}}$ & $91,00^{\mathrm{a}}$ & $83,00^{\mathrm{ab}}$ & 88,67 \\
Penyimpanan 2 & $82,00^{\mathrm{ab}}$ & $78,00^{\mathrm{b}}$ & $81,00^{\mathrm{ab}}$ & 80,33 \\
Penyimpanan 3 & $84,00^{\mathrm{ab}}$ & $86,00^{\mathrm{ab}}$ & $89,00^{\mathrm{ab}}$ & 86,33 \\
\hline Rerata & 85,00 & 86,75 & 84,25 & $(+)$
\end{tabular}

Keterangan : Angka pada barisan dan kolom diikuti huruf yang sama menunjukkan tidak beda nyata pada tingkat ( $\alpha$ ) 5\% menurut uji DMRT. (+): Terjadi Interaksi

Tabel 4. Kecepatan Tumbuh (\%/etmal)

\begin{tabular}{ccccc}
\hline \multirow{2}{*}{ Lama Penyimpanan (Bulan) } & \multicolumn{3}{c}{ Coating } & \multirow{2}{*}{ Rerata } \\
\cline { 2 - 4 } & Kontrol & PGPR & Mol & \\
\hline Tanpa (kontrol) & $16,00^{\mathrm{c}}$ & $20,42^{\mathrm{abc}}$ & $21,78^{\mathrm{ab}}$ & 20,04 \\
Penyimpanan 1 & $18,73^{\mathrm{abc}}$ & $19,01^{\mathrm{abc}}$ & $17,22^{\mathrm{abc}}$ & 18,32 \\
Penyimpanan 2 & $20,13^{\mathrm{abc}}$ & $22,29^{\mathrm{a}}$ & $18,59^{\mathrm{abc}}$ & 20,34 \\
Penyimpanan 3 & $19,79^{\mathrm{abc}}$ & $16,61^{\mathrm{c}}$ & $16,97^{\mathrm{abc}}$ & 17,79 \\
\hline Rerata & 19,14 & 19,58 & 18,64 & $(+)$ \\
\hline
\end{tabular}

Keterangan: Angka pada barisan dan kolom diikuti huruf yang sama menunjukkan tidak tidak beda nyata pada tingkat ( $\alpha$ ) 5\% menurut uji DMRT. (+): Terjadi Interaksi

\section{Keserempakan Tumbuh}

Hasil sidik ragam (anova) menunjukkan bahwa terjadi interaksi antara perlakuan coating dengan penyimpanan. Tanpa perlakuan coating pada penyimpanan bulan ke-2 menunjukkan keserempakan tumbuh tertinggi dengan presentasi $90,00 \%$ berbeda nyata dengan perlakuan coating PGPR dan perlakuan coating MOL (Tabel. 5)

Tabel 5. Keserempaka Tumbuh

\begin{tabular}{ccccc}
\hline \multirow{2}{*}{ Lama Penyimpanan (Bulan) } & \multicolumn{3}{c}{ Coating } & \multirow{2}{*}{ Rerata } \\
\cline { 2 - 4 } & Kontrol & PGPR & Mol & \\
\hline Tanpa (kontrol) & $88,00^{\text {ab }}$ & $85,00^{\text {ab }}$ & $87,00^{\text {ab }}$ & 86,33 \\
Penyimpanan 1 & $84,00^{\text {ab }}$ & $88,00^{\text {ab }}$ & $87,00^{\text {ab }}$ & 83,33 \\
Penyimpanan 2 & $90,00^{\mathrm{a}}$ & $78,00^{\mathrm{b}}$ & $82,00^{\mathrm{ab}}$ & 83,33 \\
Penyimpanan 3 & $86,00^{\mathrm{ab}}$ & $87,00^{\mathrm{ab}}$ & $81,00^{\mathrm{ab}}$ & 84,67 \\
\hline Rerata & 86,75 & 84,50 & 82,00 & $(+)$ \\
\hline
\end{tabular}

Keterangan: Angka pada barisan dan kolom diikuti huruf yang sama menunjukkan tidak beda nyata pada tingkat ( $\alpha$ ) 5\% menurut uji DMRT. (+): Terjadi Interaksi

\section{Berat Kering Kecambah Normal}

Hasil Sidik Ragam (anova) menunjukkan bahwa tidak terjadi interaksi antara perlakuan penyimpanan dan coating terhadap berat kering kecambah normal (Tabel. 6)

Tabel 6. Berat Kering Kecambah Normal

\begin{tabular}{ccccc}
\hline \multirow{2}{*}{ Lama Penyimpanan (Bulan) } & \multicolumn{3}{c}{ Coating } & \multirow{2}{*}{ Rerata } \\
\cline { 2 - 4 } & Kontrol & PGPR & Mol & \\
\hline Tanpa (kontrol) & 0,12 & 0,13 & 0,10 & $0,12^{\mathrm{a}}$ \\
Penyimpanan 1 & 0,13 & 0,11 & 0,12 & $0,12^{\mathrm{a}}$ \\
Penyimpanan 2 & 0,12 & 0,12 & 0,13 & $0,13^{\mathrm{a}}$ \\
Penyimpanan 3 & 0,12 & 0,11 & 0,11 & $0,11^{\mathrm{a}}$ \\
\hline Rerata & $0,13^{\mathrm{a}}$ & $0,12^{\mathrm{a}}$ & 0,11 & $(-)$ \\
\hline
\end{tabular}

Keterangan: Angka pada barisan dan kolom diikuti huruf yang sama menunjukkan tidak beda nyata pada tingkat ( $\alpha$ ) 5\% menurut uji DMRT. (-): Tidak Terjadi Interaksi

\section{Kejadian Penyakit}

Hasil sidik ragam (Anova) menujukkan bahwa terjadi interaksi antara perlakuan coating dengan penyimpanan. Perlakuan menujukkan bahwa ada beda nyata antara perlakuan coating PGPR dengan coating MOL. Presentasi kejadian penyakit tertinggi $89.00 \%$ terdapat pada penyimpanan bulan ke-3 dan prosentase terendah $12.00 \%$ terdapat pada penyimpanan bulan ke-1 (Tabel.7).

Tabel 7. Kejadian Penyakit

\begin{tabular}{ccccc}
\hline \multirow{2}{*}{ Lama Penyimpanan (Bulan) } & \multicolumn{3}{c}{ Coating } & \multirow{2}{*}{ Rerata } \\
\cline { 2 - 4 } & Kontrol & PGPR & Mol & \\
\hline Tanpa (kontrol) & $13,00^{\mathrm{b}}$ & $16,00^{\mathrm{b}}$ & $16,00^{\mathrm{b}}$ & $15,00^{\mathrm{c}}$ \\
Penyimpanan 1 & $15,00^{\mathrm{b}}$ & $12,00^{\mathrm{b}}$ & $78,00^{\mathrm{a}}$ & $35,00^{\mathrm{b}}$ \\
Penyimpanan 2 & $24,00^{\mathrm{b}}$ & $22,00^{\mathrm{b}}$ & $78,00^{\mathrm{a}}$ & $41,33^{\mathrm{a}}$ \\
Penyimpanan 3 & $17,00^{\mathrm{b}}$ & $17,00^{\mathrm{b}}$ & $89,00^{\mathrm{a}}$ & $41,00^{\mathrm{a}}$ \\
\hline Rerata & 17,25 & 16,75 & 65,25 & $(+)$ \\
\hline
\end{tabular}

Keterangan: Angka pada barisan dan kolom diikuti huruf yang sama menunjukan tidak berbeda nyata pada tingkat nyata( $\alpha$ ) 5\% menurut uji DMRT. (+): Terjadi Interaksi 


\subsection{Pembahasan}

Perlakuan pelapis benih dalam perindustrian yang terlalu efektif dapat dimanfaatkan untuk memperbaiki penampilan benih dan ukuran beni, dapat mempertahankan daya simpan benih, menguragi resiko kejadian penyakit pada benih, dan dapat dimanfaatkan juga sebagai pewarna zat adektif, seperti anti oksidan, anti mikroba, repellent, mikroba antogonis, zat pengatur tumbuh dan sebagainya (Ilyas, 2003).PGPR merupakan salah satu bakteri yang merangsang pertumbuhan tanaman yang hidup di risosfer tanaman dan dapat dimanfaatkan sebagai agen hayati untuk mengendalikan beberapa jenis patogen. Perlakuan pada benih dengan menggunakan PGPR dapat mempertahankan tanaman terhadap serangan paotogen dan bersifat endofitik ( berada dalam jaringan tanaman dan tidak dapat membahayakan tanaman). Salah satu manfaat PGPR yang tepat adalah dapat digunkan saat tanaman berada pada masa vegetatif agar dapat mengurangi kebutuhan dapat diaplikasikan lebih lanjut pada bagianbagian vegetatif yang sama manfaatnya sebgai bahan propogatif (Ramamoorthy et al. 2000).Penyimpanan benih dapat dilakukan pada benih-benih yang secara tidak langsung untuk digunakan dalam proses produksi karena dapat dimodifikasi pada ruangan penyimpanan maka dengan secara perlahan benih tersebut akan mengalami kemunduran. Laju kemunduran pada benih tersebut dapat berbeda-beda antara satu dengan yang lainnya.

Justice \& Bass, 2002 mengatakan bahwa proses penguapan dapat terjadi karena pada masa penyimpanan dapat memperlambat rantai asam lemak tak jenuh sehingga dapat menghasilkan radikal-radikal bebas yang dapat berpengaruh dengan lipida sehingga dapat merusak struktrur memberan sel.Penyakit terbawa benih dapat menyebabkan kerugian antara lain benih busuk,nekrosis dan menurunnya nutrisi dan kehilangan viabilitas benih pada coating selama penyimpanan sehingga penyakit terbawa benih dapat terbawa sampai ke bibit sehinnga dapat mempengaruhi coating dan penyimpanan (Pawar, 2011). Selain penyakit terbawa benih, kejadian penyakit juga disebabkan oleh faktoer lingkungan saat seedcoating, diduga benih terkontaminasi dengan patogen lingkungan.

\section{Simpulan}

Berdasarkan hasil penelitian dapat disimpulkan bahwa terjadi interaksi pada semua parameter pengamatan kecuali pada parameter pengamatan berat kecambah normal, dengan kombinasi perlakuan terbaik adalah perlakuan coating dengan PGPR dengan lama penyimpanan 1 bulan yang ditunjukkan dengan parameter pengamatan daya berkecambah terbaik, indeks vigor terbaik, dan kejadian penyakit terendah.

\section{Pustaka}

Badan Pusat Statistik. 2009. Luas Panen-ProduktivitasProduksi Tanaman Padi Seluruh Provinsi di Indonesia.

Copeland, L. O and M. B. Mc Donald. 2001. Principle of Seed Science and Technology. 4th Edition.Kluwer Academic Publisher.United States of America.p 467.

Hendarto, K. 2005. Dasar-dasar Teknologi dan Sertifikasi Benih. Andi Offset : Yogyakarta.

Ilyas, S. 2003. Teknologi Pelapisan Benih. Makalah Seminar Benih Pellet. Departemen Budidaya Pertanian, Faperta IPB. 16 hal.

Ilyas S. 2012. Ilmu dan Teknologi Benih: Teori dan Hasil-hasil Penelitian. IPBPress, Bogor.

Justice O. L. and L. N. Bass. 2002. Prinsip dan Praktek Penyimpanan Benih (terjemahan). Raja Grafindo Persada, Jakarta. 446 hal.

Kuswanto, H. 2003. Teknologi Pemrosesan, Pengemasan dan Penyimpanan. Kanisius. Yogyakarta.

Millan, Mc. S. 2007. Promoting Growth With PGPR. The Canadian Organic Grower. Hlm.32-34

Pawar, B. T. 2011. Antifungal Activity of Some Leaf Extracts Againts Seedborne Pathogenic Fungi. International Multidisciplinary Research Journal 1 (4) : $11-13$.

Ramamoorthy V, Viswanathan R, Raguchander T, Prakasam V, Samiyappan R. 2000. Induction of systemic resistance by plant growth promoting rhizobacteria in crop plants against pests and diseases. Crop Protection 20 (2001):1-11.

Zadok JC, Schein RD. 1979. Epidemology and Plant Disease Management. New York (USA): Oxford University Press. p 417. 